\title{
Efektivitas Mendongeng Untuk Meningkatkan Pemahaman Respek Kepada Lingkungan Pada Anak Usia 5-6 Tahun
}

\author{
Melissa Tuanakotta1 \\ Wahyu Indianti \\ S2 Terapan Psikologi Anak Usia Dini \\ Fakultas Psikologi Universitas Indonesia
}

\begin{abstract}
In today's modern society, including in Indonesia, there is an environmental crisis. This environmental crisis can be overcome by changing people's behavior and perspective by intervening to the community as early as possible. Storytelling can be one way to increase children's understanding about respect for nature. This study aims to knowing the effectiveness of storytelling to increase understanding of respect for nature in children aged 5-6 years. This study involving 31 children from TK Negeri Pembina, Kuningan, as participants. Intervention is done by reading four tales in four days. Understanding of respect for nature is measured using a measurement tool created by the researcher, in the form of six illustrations that depicting the behavior of respect for nature. The statistic analysis using Wilcoxon signed-rank test showed the difference of mean value of respect for nature understanding is significant $(p<0.05)$ between before and after reading tales. The result of post-test 2 , which done two weeks after the intervention still shows an increase score from the pre test.
\end{abstract}

Key words: story-telling, respect, respect for nature, teaches respect for children, moral, character

\begin{abstract}
ABSTRAK: Krisis lingkungan merupakan permasalahan dunia, termasuk Indonesia. Manusia merupakan agen utama dari kerusakan lingkungan itu sendiri. Salah satu solusi untuk itu adalah mengubah perilaku dan cara pandang manusia terhadap alam. Upaya itu dapat dilakukan dengan memberi intervensi kepada masyarakat sedini mungkin. Mendongeng terbukti dapat meningkatkan pemahaman anak tentang respek kepada lingkungan. Penelitian ini bertujuan untuk mengetahui efektivitas mendongeng untuk meningkatkan pemahaman respek kepada lingkungan pada anak usia 5-6 tahun. Penelitian ini melibatkan 31 partisipan dari TK Negeri Pembina, Kuningan. Intervensi dilakukan dengan membacakan empat dongeng selama empat hari.Pemahaman respek kepada lingkungan diukur dengan menggunakan alat ukur yang dibuat peneliti, berupa enam ilustrasi yang menggambarkan perilaku respek kepada lingkungan. Dari hasil analisis statistik Wilcoxon signed-rank test menunjukkan perbedaan nilai rata-rata respek kepada lingkungan yang signifikan $(\mathrm{p}<0,05)$ antara sebelum dan sesudah dibacakan dongeng. Hasil post-test 2 yang dilaksanakan dua minggu setelah intervensi masih menunjukkan peningkatan skor dari pre-test. Mendongeng terbukti berpengaruh pada cara pandang anak terhadap lingkungannya. Ini sangat positif bagi upaya pelestarian lingkungan.
\end{abstract}

Kata kunci: mendongeng, respek, respek kepada lingkungan, mengajarkan respek kepada anak, moral, karakter

${ }^{1}$ Korespondensi mengenai isi artikel ini dapat dilakukan melalui: emailissatuanakotta@gmail.com 
Krisis moral tidak hanya akan menimbulkan perilaku negatif kepada diri sendiri atau orang lain, tapi juga kepada lingkungan. Keraf (2002) menyatakan krisis lingkungan hidup yang terjadi sekarang ini sebagian besar bersumber dari perilaku manusia yang tidak memiliki moral. Selain dikarenakan faktor alam seperti perubahan iklim, kerusakan lingkungan juga disebabkan faktor manusia, seperti pencemaran lingkungan dan eksploitasi sumber daya alam untuk memenuhi kebutuhan tanpa memperhatikan kelestarian lingkungan. Menurut Pusat Krisis Kementrian Kesehatan (2016) kerusakan lingkungan saat ini sudah memasuki tahap darurat. Salah satu contoh nyatanya terjadi di daerah Taman Nasional Gunung Ciremai. Di kawasan cagar alam tersebut masih marak terjadi perburuan liar, pembukaan hutan untuk lahan pertanian dan perkebunan, serta perdagangan sumber daya alam yang berada di dalamnya (Ceepo, 2013). Oknum-oknum yang melakukan tindakan perusakan lingkungan tersebut adalah manusia yang seharusnya menjadi pelaku moral yang memiliki kewajiban untuk menjaga dan melindungi semua kehidupan di Bumi.Walaupun sudah ada larangan untuk mengeksploitasi hutan, masih ada saja masyarakat yang belum menaatinya.Kelompok masyarakat tersebut menganggap hutan dan segala kekayaan di dalamnya bebas untuk dimanfaatkan bagi kepentingan pribadi maupun kelompoknya (Mus, 2014).Bukan hanya orang dewasa saja yang melakukan perilaku negatif, anak-anak pun banyak yang melakukannya.Dari hasil elisitasi yang dilakukan di daerah kaki Gunung Ciremai, diketahui bahwa anakanak masih membuang sampah sembarangan, merusak tanaman, dan menyakiti binatang.
Perilaku-perilaku tersebut nampak jelas kurang ramah terhadap lingkungan. Padahal, berdasarkan teori biosentrisme setiap kehidupan dan makhluk hidup mempunyai nilai dan berharga pada dirinya sendiri, sehingga pantas mendapat pertimbangan dan kepedulian moral. Semua organisme hidup dan kelompok organisme tertentu adalah sebuah subyek moral, yaitu makhluk yang harus diperlakukan secara baik atau buruk, dan pelaku moral mempunyai kewajiban dan tanggungjawab terhadapnya. Sebagai pelaku moral manusia dengan sendirinya mempunyai kewajiban dan tanggung jawab moral atas keberadaan dan kelangsungan hidup semua organisme karena mereka adalah subyek moral. Hanya manusia yang tahu mengenai baik dan buruk secara moral yang mempunyai dorongan dan tanggung jawab moral untuk menjaga dan melindungi semua kehidupan di Bumi, termasuk yang bukan manusia (Keraf, 2002).

Krisis lingkungan hidup ini bisa diatasi dengan mengubah perilaku dan cara pandang manusia terhadap alam secara mendasar. Masyarakat membutuhkan sebuah pola hidup dan gaya hidup baru yang mampu menuntun manusia untuk berinteraksi dengan alam semesta. Akan tetapi mengubah perilaku dan cara pandang mengenai hubungan antara manusia dan lingkungan amat sulit dilakukan pada orang dewasa (Gardner \& Stern, 1996) karena perilakunya sudah menetap dan lebih sulit untuk diubah. Oleh karena itu intervensi perlu dilakukan sedini mungkin agar perilaku destruktif yang merusak lingkungan tersebut tidak berkelanjutan. Anak usia dini masih mudah menyerap informasi karena mereka belum memiliki informasi sebelumnya, sehingga pengetahuannya pun masih mudah dibentuk (Keraf, 2002). 
Intervensi yang dilakukan kepada anak usia dini, 5-6 tahun, juga dapat mencegah anggapan bahwa lingkungan yang telah rusak adalah suatu kondisi yang normal (Khan, 2001). Hal tersebut dikarenakan, lingkungan hidup bagi anak bukan hanya sekedar konsep yang merupakan hasil kesepakatan kultural namun merupakan bagian dari realitas fisik dan biologi yang juga mencakup kognisi mereka (Soule \& Lease 1995, dalam Kahn, 2001). Sangat memungkinkan bagi anak dibesarkan di lingkungan yang kental dengan perilaku yang tidak menghargai lingkungan, maka anak akan menganggap hal tersebut sebagai kondisi yang normal. Oleh karena itu diperlukan pembentukan pola pikir sedini mungkin, agar anak paham bahwa mereka harus menghargai alam dengan tidak melakukan perilaku negatif kepada lingkungannya.

Salah satu intervensi yang bisa dilakukan untuk mengatasi krisis lingkungan hidup adalah dengan mengajarkan anak usia dini virtue respek. Respek adalah menghargai seseorang atau sesuatu (Borba, 2001). Seseorang di sini meliputi diri sendiri maupun orang lain, sedangkan sesuatu meliputi segala bentuk kehidupan. Dari hasil penelitian yang dilakukan Kahriman-Ozturk, Olgan dan Tuncer (2012) diketahui bahwa anak-anak usia 5-6 tahun sudah memiliki kemampuan ekosentrik, kemampuan untuk mempengaruhi, mengendalikan dan bahkan melindungi lingkungan.

Ärlemalm-Hagsér (2013) menyatakan pandangan anak-anak tentang lingkungan dan partisipasi mereka kepada lingkungan dipengaruhi dua jenis konten pengetahuan, yaitu pengetahuan mereka tentang lingkungan yang disertai kedekatan mereka dengan lingkungan tersebut dan respek kepada lingkungan. Taylor (1986) juga menyatakan kewajiban utama manusia sebagai pelaku moral terhadap alam sebagai subyek moral adalah respek kepada lingkungan. Menurutnya respek kepada lingkungan adalah sikap menghargai dan menghormati alam yang diwujudkan ke dalam empat kewajiban, yang terdiri dari: 1 . Kewajiban tidak melakukan sesuatu yang merugikan alam dan segala isinya, 2 . kewajiban tidak mencampuri kehidupan organisme lain, 3. kewajiban akan janji untuk tidak memperdaya, menjebak, dan menjerat binatang liar. 4. Terakhir, kewajiban restitutif atau keadilan retributif. Kewajiban-kewajiban ini harus dilakukan agar alam semesta sebagai tempat tinggal manusia bisa terjaga kelestariannya.

Ada empat kewajiban yang dapat ditanamkan pada manusia untuk respek kepada lingkungan kepada anak usia 5-6 tahun, caranya adalah dengan mulai memberikan peraturan kepada anak-anak. Anak berusia 5-6 tahun berada dalam tahap moralitas heteronom (Kohlberg, dalam Santrock, 2002), tahap di mana tingkah laku anak-anak diatur berdasarkan apa yang dianggap benar atau salah oleh orang dewasa, anak-anak menilai suatu hal itu baik atau buruk berdasarkan konsekuensinya (Piaget, dalam Santrock, 2007). Pemahaman mereka tentang moralitas dan nilai-nilai yang dimiliki sangat bergantung dan dipengaruhi orang dewasa. Bila orang dewasa ingin mengajarkan respek terhadap lingkungan kepada anak-anak, mereka bisa membuat aturan berdasarkan empat kewajiban manusia agar respek kepada lingkungan, seperti selalu membuang sampah pada tempatnya, tidak merusak tanaman, tidak mengganggu atau mengurung binatang, janji untuk tidak memperdaya, menjebak, dan menjerat binatang, serta memulihkan kembali kesalahan yang pernah dibuatnya dan merugikan alam. Aturan-aturan tersebut harus diiringi dengan menerapkan prinsipprinsip konsekuensi positif dan negatif. Dengan menerapkan peraturan seperti ini, anak akan memiliki pengetahuan tentang respek kepada lingkungan, keinginan untuk 
respek kepada lingkungan, dan pada akhirnya melakukan kewajiban-kewajiban untuk respek kepada lingkungan. Hal ini sesuai dengan tiga unsur pokok dari pendidikan karakter, mengetahui kebaikan, mencintai kebaikan, dan melakukan kebaikan (Lickona, 1991).

Untuk mengajarkan kewajibankewajiban tersebut kepada anak tidaklah mudah. Syarat agar anak bisa meningkatkan frekuensi dan menginternalisasi perilaku yang diajarkan, maka anak ketika melakukan perilaku-perilaku tersebut harus diberikan penguatan (Borba, 2001). Perilaku harus dilakukan secara terus menerus agar bisa menjadi kebiasaan hingga kemudian menjadi karakter. Selain membuat aturan, orang dewasa juga harus mampu menjadi contoh (Borba, 2001). Hal tersebut dikarenakan anak-anak yang masih egosentris menilai hal-hal yang benar dan salah berdasarkan dari hasil observasi mereka terhadap segala sesuatu yang nyata (Piaget, dalam Thompson, 2011).

Respek kepada lingkungan pertama kali bisa diajarkan kepada anak dalam lingkup keluarga, sebagai bagian dari mikrosistem. Anggota Keluarga, terutama orang tua, adalah orang yang paling besar pengaruhnya untuk mengajarkan moral (Lickona,1991). Usia 5-6 merupakan usia pra sekolah, anak sudah mulai belajar dan bermain di taman kanak-kanak tingkat B. Ketika anak mulai bersekolah maka peran orangtua akan digantikan guru, sebagai tokoh dewasa signifikan di sekolah yang ditemui anak setiap hari.

Guru bisa memberikan keteladanan secara langsung dengan menunjukkan kepada anak bagaimana cara memulai berperilaku respek dan memperlakukan mereka secara respek (Borba, 2001). Selain itu, guru juga bisa mengajarkan keteladanan respek melalui diskusi, ceramah, dan bercerita atau mendongeng (Lickona, 1991). Diskusi dan ceramah baru bisa diaplikasikan pada usia tertentu, akan tetapi bercerita dan mendongeng bisa diberikan kepada semua usia (Lane \& Wright, 2007), termasuk anak usia 5-6 tahun. Metode ini bisa digunakan karena anak usia 5-6 tahun berada dalam tahap berpikir pra-operasional yang sudah menunjukkan kemajuan kemampuan pemikiran simbolis, sehingga dapat menggunakan simbol-simbol kata, gambar, atau angka. Anak sudah mempunyai pemahaman mengenai ruang, memahami sebab akibat, memahami identitas, memahami angka, mampu mengategorikan, dan anak-anak menjadi lebih sadar akan fungsi dari pikiran, yang berupa kemampuan untuk membedakan tampilan dari kenyataan, kemampuan membedakan fantasi dengan realita (Papalia \& Marorell, 2014). Dalam aspek perkembangan bahasa anak usia 5-6 tahun sudah mampu bercakapcakap, mulai belajar peran dan sopan ketika berbicara dengan orang lain, dan membicarakan kemungkinan yang akan terjadi. Selain itu, anak sudah mulai bisa mengambil perspektif orang lain sehingga dapat berempati atau merasakan apa yang dirasakan orang lain, Dengan kemampuan kognitif dan bahasa yang dimilikinya, anak dinilai bisa memahami simbol, gambar ilustrasi, dan mengembangkan imajinasi dari tokoh dongeng. Melalui cerita dongeng, anak juga akan digiring perspektifnya agar dapat menciptakan empati terhadap segala bentuk kehidupan yang ada di alam semesta.

Dari hasil penelitian yang dilakukan Rahasya (2017), diketahui bahwa anak-anak dapat melakukan refleksi dari sebuah dongeng dan dapat menunjukkan perilaku respek melalui refleksi yang mereka lakukan. Dari penelitian tersebut juga diketahui bahwa metode mendongeng berguna bagi guru untuk mengajarkan suatu karakter, seperti respek, melalui suatu narasi dongeng jika metode dipersiapkan dengan baik. Metode ini merupakan suatu program pendidikan yang dapat mengubah perilaku melalui informasi dari isi dongeng yang sebagian besar menggunakan 
pendekatan moral, religius, dan etika. Dalam pendekatan moral, cerita yang diangkat dalam dongeng pada umumnya menyiratkan pesan moral di dalamnya (Hibana dalam Kusmiadi, 2008). Pesan moral tersebut biasanya tercermin dari tingkah laku para tokoh dongeng. Tidak ubahnya seekor semut pekerja yang rajin dan bertanggung jawab yang tak mengenal lelah ketika mencari makanan. Mendongeng merupakan salah satu teknik yang dinilai cukup efektif karena mendongeng mengajarkan nilai moral dengan cara menarik dan tidak memaksa. Cerita di dalam dongeng akan membuat pendengarnya berimajinasi dan tersentuh hatinya, sehingga bisa menimbulkan pemahaman yang jelas tentang moral.

Isbell (2002, dalam Henniger, 2009) menyatakan bahwa pengalaman dari mendengarkan sebuah dongeng lebih personal dan terhubung dengan para pendengarnya akibat kontak mata dan penyesuaian penyampaian cerita yang dilakukan para pendongeng secara lebih spesifik. Materi dongeng diberikan dengan menggunakan bahasa, intonasi vokal, gerakan isyarat, ekspresi muka, dan gerakan tubuh, sehingga menjadi lebih mudah dipahami pendengarnya. Untuk bisa melakukan hal tersebut seorang pendongeng dituntut untuk memiliki keterampilan mendongeng.

Berdasarkan latar belakang di atas, penulis melakukan penelitian mengenai efektivitas mendongeng untuk meningkatkan pemahaman respek kepada lingkungan. Subjek pada penelitian ini adalah 31 anak usia 5-6 tahun yang sekolah di kaki Gunung Ciremai, tepatnya di TK Negeri Pembina, Dusun Kliwon, Panis, Kecamatan Pasawahan, Kuningan. Mendongeng dilakukan oleh pendidik anak usia dini yang sudah mengikuti pelatihan mendongeng. Pemahaman anak tentang respek kepada lingkungan akan dinilai sebelum dan sesudah diberikan dongeng. Setelah mendongeng, anak akan diajak untuk merefleksikan cerita dongeng dengan melakukan tanya jawab untuk mengetahui sejauh mana anak memahami perilakuperilaku apa saja yang termasuk respek kepada lingkungan. Diharapkan anak mampu menghubungkan dongeng dengan situasi nyata dan dapat mengetahui contohcontoh perilaku respek kepada lingkungan.

Respek adalah sikap menunjukkan rasa hormat sebagai bentuk penghargaan terhadap seseorang atau sesuatu (Borba, 2001; Lickona, 1992). Seseorang di sini meliputi diri sendiri maupun orang lain, sedangkan sesuatu meliputi segala bentuk kehidupan dan lingkungan yang menopang. Lickona (1992) menyebutkan bahwa respek memiliki tiga bentuk, yaitu: respek terhadap diri sendiri, terhadap orang lain, dan kepada lingkungan.

Penelitian ini lebih menitikberatkan bentuk respek kepada segala bentuk kehidupan dan lingkungan yang menopang. Bentuk respek ini melarang orang untuk berbuat kejam kepada hewan serta memiliki kepedulian terhadap lingkungan dan ekosistem. Manusia dituntut untuk merawat Bumi dan makhluk hidup seperti hewan dan tumbuhan.

Taylor (dalam Keraf, 2002) memaparkan ada empat kewajiban utama manusia untuk dapat respek kepada lingkungan, antara lain:

1. Kewajiban untuk tidak melakukan sesuatu yang merugikan alam dan segala isinya (nonmaleficence atau no harm). Manusia dituntut secara moral untuk menahan diri agar tidak melakukan sesuatu yang negatif dan destruktif merugikan dan merusak alam semesta serta segala isinya.

2. Kewajiban untuk tidak mencampuri (non-interference). Ada dua kewajiban yang terkait. Pertama kewajiban untuk tidak membatasi dan menghambat kebebasan organisme untuk berkembang dan hidup secara leluasa di alam sesuai 
dengan hakikatnya. Ini mencakup hambatan eksternal yang bersifat positif (dikurung, diikat); hambatan eksternal yang bersifat negatif (tidak tersedia air, tidak tersedia makanan); hambatan internal positif (disemprotkan bahan kimia, direkayasa secara genetik); hambatan internal negatif (kelemahan dan ketidakberdayaan karena rusaknya organ atau jaringan tertentu dalam tubuhnya. Kedua, kewajiban untuk membiarkan organisme berkembang sesuai dengan hakekatnya. Termasuk di dalamnya tidak memindahkan mereka dari habitatnya yang asli.

3. Kesetiaan kepada semacam "janji" terhadap binatang liar untuk tidak diperdaya, dijebak, dan dijerat. "Janji" ini muncul ketika seseorang pernah memperdaya, menjebak, dan menjerat, kemudian melepaskan binatang liar. Kewajiban ini lebih berlaku dalam relasi antara individu tertentu dengan binatang tertentu untuk dijaga dan dibiarkan hidup di alam bebas.

4. Kewajiban restitutif atau keadilan retributif. Kewajiban ini menuntut agar manusia memulihkan kembali kesalahan yang pernah dibuatnya dan menimbulkan kerugian terhadap alam, dalam bentuk kerusakan atau pencemaran lingkungan. Manusia diwajibkan untuk mengembalikan alam yang telah dirusaknya ke kondisi semula.

Dalam penelitian ini, peneliti menggunakan empat kewajiban utama manusia untuk respek kepada lingkungan sebagai indikator respek dan kemudian dijabarkan menjadi item-item yang mewakili perilaku respek kepada lingkungan sebagai panduan dalam pembuatan alat ukur. Untuk menyesuaikan dengan lokasi penelitian di lingkungan sekolah maka item-item dijabarkan lagi dalam bentuk perilaku respek kepada lingkungan yang sering dilakukan anak-anak di lingkungan sekolah, sebagai lembar observasi.

Perilaku yang mendukung kewajiban untuk tidak melakukan sesuatu yang merugikan alam dan segala isinya, yaitu menjaga kebersihan lingkungan dan memelihara lingkungan. Perilaku yang mendukung kewajiban untuk tidak merusak lingkungan terbagi menjadi: Perilaku untuk tidak membatasi dan menghambat kebebasan organisme untuk berkembang dan hidup, yaitu menyayangi dan memelihara binatang peliharaan, serta perilaku untuk tidak membiarkan organisme berkembang sesuai dengan hakikatnya, yaitu melindungi satwa liar. Perilaku yang mendukung kewajiban untuk kesetiaan yaitu berjanji untuk tidak memperdaya, menjebak, dan menjerat satwa liar. Yang terakhir, perilaku yang mendukung kewajiban untuk restitutif atau keadilan retributif yaitu mengembalikan alam yang telah dirusak ke kondisi semula.

Syarat agar anak dapat mengamalkan nilai-nilai respek yang ditanamkan orangtua, sebaiknya orangtua mengajarkan makna dari respek itu sendiri. Borba (2001) mendesain tiga teknik untuk membantu anak memahami arti dari respek dan mengapa respek merupakan aspek penting yang harus dimiliki. Tiga teknik tersebut adalah, menjelaskan arti respek, memberikan peraturan, dan menanamkan aturan-aturan berperilaku respek.

Langkah-langkah pada tahapan ini juga bisa diterapkan untuk mengajarkan anak respek kepada lingkungan. Dalam penelitian ini respek kepada lingkungan diperagakan dan diajarkan melalui mendongeng. Pada dongeng yang disajikan dalam penelitian ini, akan dijelaskan apa yang dimaksud dengan bersikap respek kepada lingkungan, bentuk-bentuk perilaku 
respek kepada lingkungan, bagaimana orang lain menilai anak jika mereka respek atau tidak respek kepada lingkungan, dan dampak dari sikap respek kepada lingkungan.

Melalui dongeng, anak akan diberitahu juga bahwa ada peraturan di dunia ini yang mengatakan bahwa perlakukanlah lingkungan hidup sebagaimana dia ingin diperlakukan. Cara sederhana untuk mengetahui apakah perilaku anak respek atau tidak adalah dengan bertanya kepada dirinya sendiri apakah yang dia lakukan merupakan perilaku respek kepada lingkungan atau tidak. Cara ini akan membantu anak untuk memikirkan perilaku dan konsekuensinya. Selain itu cerita dongeng juga akan berisi peraturan-peraturan untuk berperilaku respek kepada lingkungan, seperti tidak membuang sampah sembarangan, tidak memetik bunga sembarangan, dan tidak menyakiti binatang.

Untuk pemahaman anak tentang respek kepada lingkungan, anak akan diberikan alat ukur berupa kuisioner. Pengisian kuisioner dilakukan dengan wawancara semi terstruktur, yang pertanyaan-pertanyaannya disusun berdasarkan pengetahuan moral, perasaan moral, dan perilaku moral (Lickona, 1992).

Mendongeng merupakan salah satu teknik pengajaran moral yang tidak langsung tetapi dinilai cukup efektif. Ketika mendengarkan dongeng, anak akan memahami isi cerita di dalamnya dan mempelajari pesan yang ada di dalamnya (Lickona, 1991). Mendongeng bukan hanya sekedar membacakan cerita. Menurut Moeslichatoen (dalam Kusmiadi, 2008) mendongeng memiliki beberapa teknik pembacaan cerita agar menjadi lebih menarik dan bisa diterima dengan baik oleh anak. Teknik mendongeng yang paling dasar adalah membaca langsung dari buku dongeng. Teknik ini menjadi efektif dan menarik apabila buku yang digunakan pendongeng juga menarik dan cocok untuk anak. Indikator mendongeng efektif adalah jika dongeng bisa dipahami anak dan anak dapat menangkap pesan yang disampaikan. Selain itu anak juga mampu memahami perbuatan baik atau buruk dari dongeng yang dibacakan. Akan lebih baik lagi jika pendongeng bisa mengingat isi cerita dongeng tanpa harus melihat buku, karena pendongeng bisa sekaligus menggunakan teknik dramatisasi. Ketika mendongeng, seorang pendongeng harus memainkan perwatakan tokoh-tokoh. Dongeng tidak akan menjadi menarik jika pendongeng membawakan perwatakan tokoh-tokoh tersebut dan suatu peristiwa tanpa ekspresi. Dengan dramatisasi, pendongeng bisa menyesuaikan pembawaan cerita sehingga perwatakan suatu tokoh pun menjadi lebih hidup dan suatu peristiwa menjadi lebih mengesankan. Untuk memandu imajinasi anak, maka pendongeng bisa menggunakan ilustrasi yang menarik sebagai alat bantu, tujuannya untuk memperjelas pesan-pesan yang ingin disampaikan dan dapat menarik perhatian anak pada alur cerita.

Speaker (2000) menegaskan seorang pendongeng harus memperhatikan beberapa hal agar dongeng menjadi menarik dan efektif. Hal-hal tersebut adalah: pilihan dongeng, pelajari isi dongeng sebelum mendongeng, komitmen, intonasi yang jelas dan kontak mata dengan anak, variasi suara, gerak tubuh dan ekspresi wajah, santai serta percaya diri. Durasi mendongeng juga menjadi salah satu hal yang cukup penting untuk dipertimbangkan karena rentang perhatian anak terhadap suatu hal tidak terlalu lama. Di setiap usia anak memiliki rentang perhatian yang berbeda. Anak berusia 5-6 tahun pada umumnya memiliki rentang perhatian kurang dari 20 menit (Hauser-Lindstrom, dan Steinfelt, 1998).

Keterlibatan pendidik anak usia dini bisa dilakukan dengan PEER (Prompt, Evaluate, Expand, dan Repeat). Pendidik memberikan instruksi kepada anak untuk 
menyampaikan tentang dongeng yang baru diberikan, kemudian mengevaluasi respon anak dan memperluas arti respon dengan menambahkan informasi atau mengubah kalimat yang sudah direspon anak, selanjutnya pendidik mengulang respon yang telah diperkaya dan meminta anak untuk mengulang sehingga anak dapat memahaminya (What Works Clearing House, 2007; Whitehust, 2009).

Agar anak lebih aktif dan paham kepada cerita dongeng, pendidik dapat menggunakan teknik CROWD yakni singkatan dari: Completion atau melengkapi kalimat yang belum lengkap, recall mengingat jalan cerita dengan mengajukan pertanyaan setelah selesai mendongeng, open-ended menanyakan apa yang terjadi di dalam dongeng, wh-questions menggunakan pertanyaan terbuka seperti apa, siapa, mengapa dan kapan, distancing menghubungkan cerita dongeng dengan pengalaman sehari-hari (What Works Clearing House, 2007; Whitehust, 2009).

Pada penelitian ini, peneliti akan menggunakan jenis dongeng fabel, yang tokoh utamanya adalah binatang-binatang endemik yang berada di Taman Nasional Gunung Ciremai seperti Surili dan Pelanduk Jawa. Menurut Musfiroh (2008) tema cerita yang diberikan pada anak-anak usia 5-6 tahun sebaiknya bertema moral, binatang, dan bersifat tradisional yang menceritakan tentang kebaikan, keburukan, kebenaran dan kejahatan. Cerita tentang binatang sudah digunakan sejak lama untuk mengajarkan nilai-nilai dasar dalam masyarakat. Cerita binatang memberi kesempatan kepada anak untuk belajar etika, karena binatang tidak memiliki identitas spesifik, sehingga dapat menggambarkan tentang keberagaman manusia. Karakter cerita yang digambarkan melalui binatang dapat menarik minat anak dari berbagai usia (Shepard, dalam Eder \& Hloyan, 2010).
Dongeng penelitian ini berupa cerita fiksi modern, cerita imajinatif yang diciptakan seseorang berdasarkan problematika kehidupan sehari-hari (Musfiroh, 2008). Fiksi ini mungkin merupakan potret kehidupan, namun bukan sejarah tentang suatu peristiwa atau seorang tokoh. Kejadian dan tokoh adalah hasil imajinasi pengarang, namun permasalahan yang disajikan ada dalam kehidupan manusia. Oleh karena itu, walaupun berjenis fabel, tokoh dalam dongeng tidak seluruhnya binatang, ada juga tokoh manusia di dalamnya, seperti cerita fiksi modern Winnie the Pooh.

Belajar bukan hanya menjadi kebutuhan anak saja, orang dewasa juga butuh, bedanya, hanya pada motivasi belajarnya. Seorang anak belajar untuk mempelajari hal-hal yang ingin mereka ketahui (Malouf, 1994). Orang tua belajar untuk mengembangkan kemampuan yang mereka butuhkan untuk menjalani hidup yang lebih baik lagi, karena itu pelatihan mendongeng untuk mereka juga diperlukan.

Pemberian pelatihan juga didasari hasil analisis kebutuhan. Para pendidik yang mengajar di TK Negeri Pembina, Dusun Kliwon, Kelurahan Panis, Kecamatan Pesawahan, Kuningan diketahui jarang menggunakan metode mendongeng dan kurang memiliki keterampilan mendongeng. Setelah diberi penjelasan singkat mengenai tujuan penelitian, para pendidik pun termotivasi dan ingin belajar mendongeng, berharap dapat memperkaya metode Kelompok Kerja Guru di Kecamatan.

Tugas seorang pengajar bukan hanya menanamkan ide baru, tetapi juga memodifikasi ide lama yang mungkin menghalangi ide-ide baru. Belajar adalah proses di mana pengetahuan tercipta melalui transformasi suatu pengalaman. Ada empat tahap daur belajar yang dikembangkan Kolb (dalam Laird, 2003) yaitu: Concrete Experience, di mana seseorang memperoleh pengalaman 
konkret, Observation and reflection, seseorang mulai merefleksikan dan mengamati pengalaman yang diperoleh, dan kemudian memberikan penilaian, Abstract conceptualization seseorang akan mengambil kesimpulan dari pengalaman, mengubah kesan yang didapat ke dalam berbagai pola pengalaman, konsep, hipotesa, model, dan teori supaya dapat mengambil kesimpulan dari pengalaman serupa, dan Active experimentation pada tahap ini seseorang akan menguji gagasan dalam suatu eksperimen yang kembali akan menghasilkan perilaku dan pengalaman baru.

Perubahan perilaku seseorang dimungkinkan bila dia memperoleh pengetahuan, sikap, dan keterampilan dari suatu pengalaman yang salah satunya dilakukan lewat sebuah pelatihan (Laird, 2003). Pelatihan dapat membantu seseorang untuk mempelajari suatu pengetahuan dan keterampilan teknis untuk tujuan tertentu melalui pendidikan jangka pendek (Sikula, dalam Munandar, 2001).

Tujuan dari suatu pelatihan adalah untuk mengajarkan pengetahuan dan keahlian tertentu agar seseorang menjadi semakin terampil dan bisa menjalankan tanggung jawab dengan lebih baik lagi sesuai dengan standar yang ada (Noviantoro, 2009). Selain menambah pengetahuan dan keterampilan hidup, pelatihan juga memiliki tujuan untuk mengubah perilaku seseorang (Manulang, dalam Fauzi, 2011).

\section{Metode dan Prosedur Intervensi}

Penelitian eksperimen ini menggunakan satu kelompok subjek penelitian sebagai kelompok eksperimental tanpa adanya kelompok kontrol dengan desain penelitian one group pretest posttest design. Penelitian ini memiliki dua tahap, tahap persiapan dan tahap pelaksanaan. Tahap persiapan untuk intervensi mendongeng meliputi analisis kebutuhan, tahap perizinan, menentukan tujuan intervensi, menentukan indikator perilaku, pembuatan materi dongeng, uji coba pembacaan dongeng, pembuatan alat ukur, pelatihan mendongeng, penentuan pendongeng. Untuk tahap pelaksanaan, meliputi tahap prates, intervensi, pascates serta observasi.

Partisipan akan diberikan prates sebelum mendapatkan intervensi pelatihan mendongeng, setelah itu akan dilakukan pascates 1 kepada mereka untuk mengetahui skor pengetahuan dan keterampilan mendongeng sebelum dan sesudah intervensi. Dalam jangka waktu dua minggu setelah intervensi dilakukan pascates kembali dilakukan untuk mengetahui apakah intervensi yang dilakukan masih efektif atau tidak.

Untuk mendapatkan pendongeng yang tepat dalam melakukan intervensi, saat pelatihan para pendidik diukur pengetahuannya dengan kuesioner dan keterampilan mendongengnya menggunakan behavioral checklist. Dipilih tiga orang pendidik dengan tiga skor tertinggi untuk melakukan intervensi. Sementara untuk mengukur pemahaman sikap respek kepada lingkungan, alat ukur yang digunakan berupa kuesioner yang akan disajikan dalam bentuk wawancara semi terstruktur kepada anak. Data yang telah diperoleh dianalisis dengan wilcoxon signed rank test.

\section{Hasil Penelitian}

Penelitian dilakukan terhadap 31 anak di TK Negeri Pembina di Desa Paniis, Kuningan, yang berusia 5-6 tahun. Partisipan diambil dari 3 kelas, yaitu 10 anak dari kelas B1, 10 anak dari kelas B2, dan 10 anak dari kelas B3. Jumlah peserta laki-laki 17 anak, dan peserta perempuan 14 anak. Untuk kelas B1 anak diberi intervensi mendongeng oleh $\mathrm{S}$, guru yang memiliki skor tertinggi pertama saat intervensi pelatihan mendongeng. Untuk kelas B2 anak diberi intervensi mendongeng oleh ER, guru yang memiliki skor tertinggi kedua. Untuk kelas 
B3 anak diberi intervensi mendongeng oleh $\mathrm{TH}$, guru yang memiliki skor tertinggi ketiga.

Analisis Prates-Pascates Pengetahuan Pendidik.

Perolehan skor pemahaman anak sebelum dan sesudah intervensi dapat dilihat pada gambar 1, yang menunjukan adanya peningkatan skor nilai pada semua partisipan setelah mendapat intervensi. Terdapat beberapa anak yang menunjukkan kenaikan skor cukup tinggi setelah diberikan intervensi. KI mengalami kenaikan skor 10, DC mengalami kenaikan skor 14, IL mengalami kenaikan skor 15 , dan LN mengalami kenaikan skor 11 . Pada saat prates empat orang anak RF, RI, FY, MC, sudah memiliki skor yang baik 18, setelah diberikan intervensi mendongeng, skor mereka mengalami kenaikan 1, sehingga berhasil mendapatkan nilai maksimum 19 . Dari 31 anak ada 14 anak yang berhasil mendapatkan nilai maksimum. Sementara ada tujuh orang anak, DP, SR, BY, TK, AF, GE, $A N$, yang skornya berada di bawah rata-rata. Dari hasil observasi yang dilakukan fasilitator, ketujuh anak ini kurang menaruh perhatian kepada pendongeng dan cenderung asyik bermain sendiri. Kemampuan mereka di bidang lainnya dinilai para guru memang masih tertinggal dibandingkan teman-teman seusianya. Hal tersebut bisa diketahui pada saat pemberian prates dan pascates, mereka kurang paham dengan pertanyaan yang diberikan sehingga fasilitator perlu beberapa kali mengulang pertanyaan.

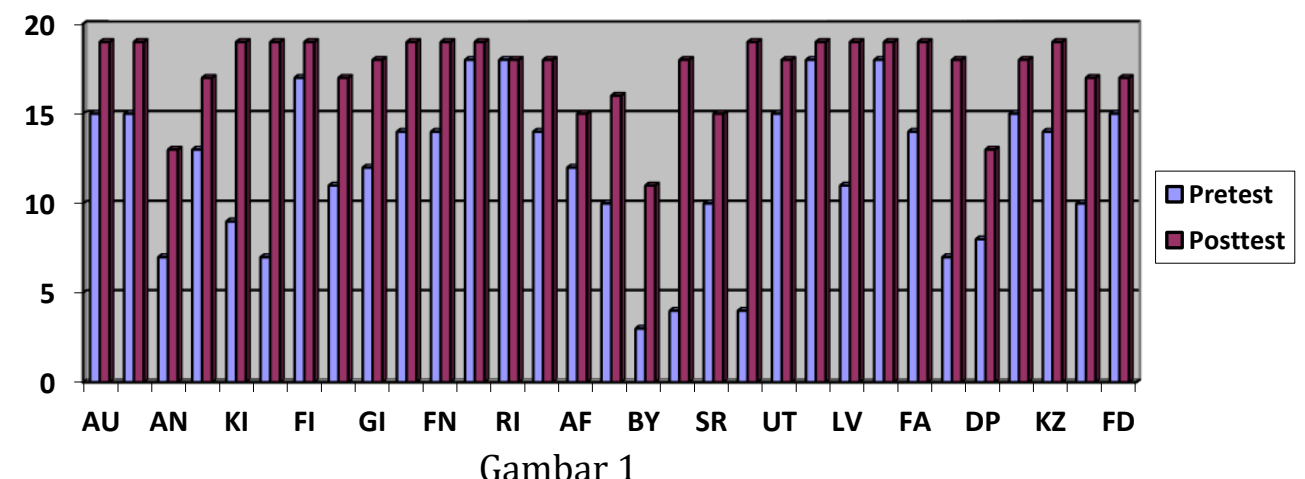

Perbandingan Skor Pemahaman Respek AUD Kepada Lingkungan

Kelas yang pendongengnya memiliki skor pengetahuan dan keterampilan dalam mendongeng paling tinggi (saat pelatihan), memiliki skor rata-rata pemahaman anak tentang respek kepada lingkungan lebih tinggi jika dibandingkan dengan anak yang mendengarkan dongeng dari pendidik yang memiliki pengetahuan dan keterampilan lebih rendah. Kelas yang pendongengnya adalah "S" memiliki skor rata-rata 18, kemudian untuk kelas yang pendongengnya adalah "ER" memiliki skor rata-rata 17,8, dan kelas yang pendongengnya adalah "TH" memiliki skor rata-rata 16,7 .

Tabel 1. Analisis Statistik Nilai Rata-Rata Prates-Pascates Pengetahuan AUD

\begin{tabular}{lllcccc}
\hline \multicolumn{1}{c}{$\mathrm{N}$} & Mean & $\begin{array}{c}\text { Std. } \\
\text { Deviasi }\end{array}$ & Minimum & Maximum & $\begin{array}{c}\mathrm{Z} \\
\text { value }\end{array}$ & $\begin{array}{c}\mathrm{p} \\
\text { value }\end{array}$ \\
\hline Prates 31 & 12 & 4,3133 & 18 & $-4,790^{\mathrm{b}}$ & 0,000002 & \\
Pascates 31 & 17,52 & 2,09611 & 19 & & & \\
\hline
\end{tabular}


Pada alat ukur pemahaman respek anak, dapat diketahui skor nilai terendah yang dapat diperoleh adalah 0 dan tertinggi adalah 19. Dari tabel 1. dapat diketahui nilai rata-rata (mean) pascates lebih besar dari nilai rata-rata prates, nilai $\mathrm{Z}$ adalah $-4,790^{\mathrm{b}}$ dan nilai $p$ adalah 0,000002 . Dengan nilai signifikansi $p<0,05$ menunjukkan perbedaan nilai rata-rata yang signifikan antara prates dan pascates. Hal itu menunjukkan terjadinya peningkatan skor pemahaman respek AUD kepada lingkungan antara sebelum dan sesudah diberikan intervensi berupa dongeng oleh tiga guru yang dimoderatori ketrampilan mendongeng.

Pascates kedua (uji tindaklanjut) dilakukan dua minggu setelah pascates pertama, yaitu pada 25 mei 2018 dan diikuti 31 partisipan. Hasil skor nilai pascates 1 ke pascates 2, dapat dilihat pada gambar 2. Dari tabel dan gambar dapat diketahui terdapat 15 partisipan yang mengalami peningkatan skor, 12 partisipan dengan skor tetap, dan 4 partisipan mengalami penurunan skor dibandingkan dengan skor pascates 1 .

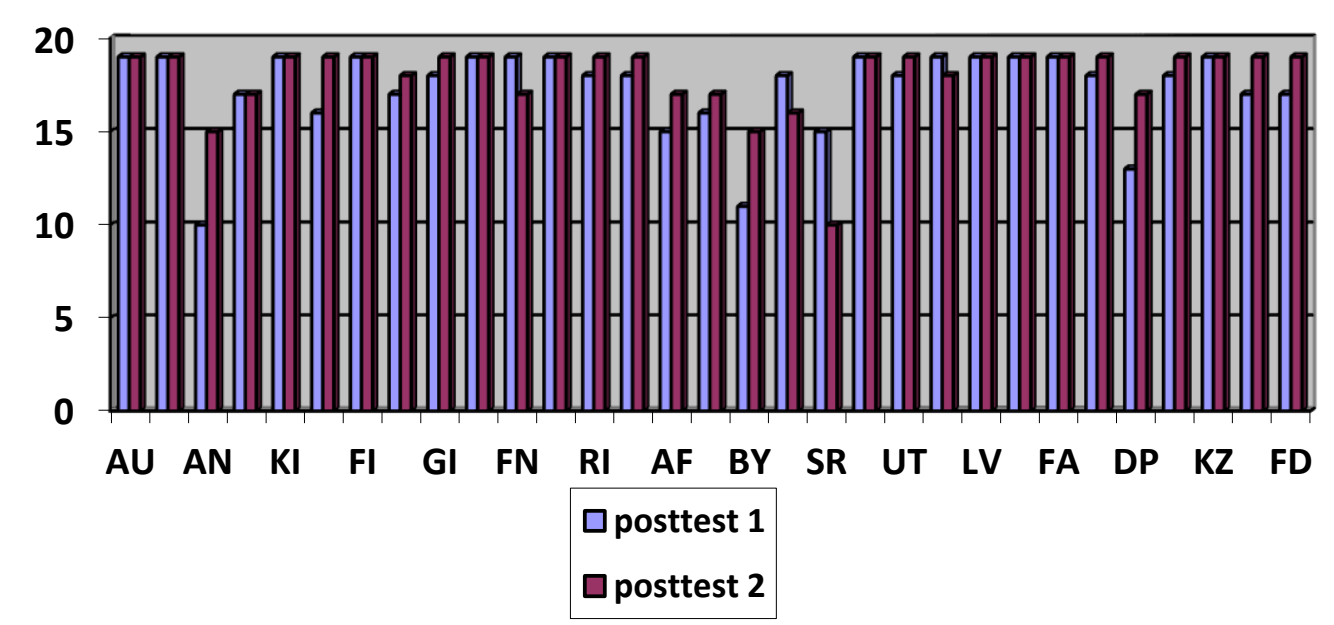

Gambar 2.

Perbandingan Skor Pascates 1 dan Pascates 2

Tabel 2. Analisis Statistik Nilai Rata-Rata Pascates 1 - Pascates 2

\begin{tabular}{|c|c|c|c|c|c|c|}
\hline $\mathrm{N}$ & Mean & Std. Dev. & Minimum & Maksimum & $\mathrm{Z}$ & $\mathrm{p}$ \\
\hline Pascates 131 & 17,32 & 2,358 & 10 & 19 & $-1,940^{b}$ & 0,052 \\
\hline Pascates 231 & 17,97 & 1,923 & 10 & 19 & & \\
\hline
\end{tabular}

Tabel 2 menunjukkan nilai rata-rata pascates 2 lebih besar dari nilai rata-rata pascates 1 . Sedangkan nilai Z adalah $-1,940^{\mathrm{b}}$ dan nilai $p$ adalah 0,052 . Dengan nilai signifikansi $\mathrm{p}<0,05$, menunjukkan tidak ada perbedaan nilai rata-rata yang signifikan antara pascates 1 dan pascates 2. Dari hasil analisis statistik dapat diketahui terdapat peningkatan skor pemahaman anak tentang respek kepada lingkungan pada pascates 2 
yang dilakukan dua minggu setelah intervensi, namun peningkatan skor tersebut tidak signifikan. Dengan demikian dapat dikatakan bahwa efektivitas mendongeng untuk meningkatkan pemahaman anak terhadap perilaku respek kepada lingkungan masih menetap setelah dua minggu.

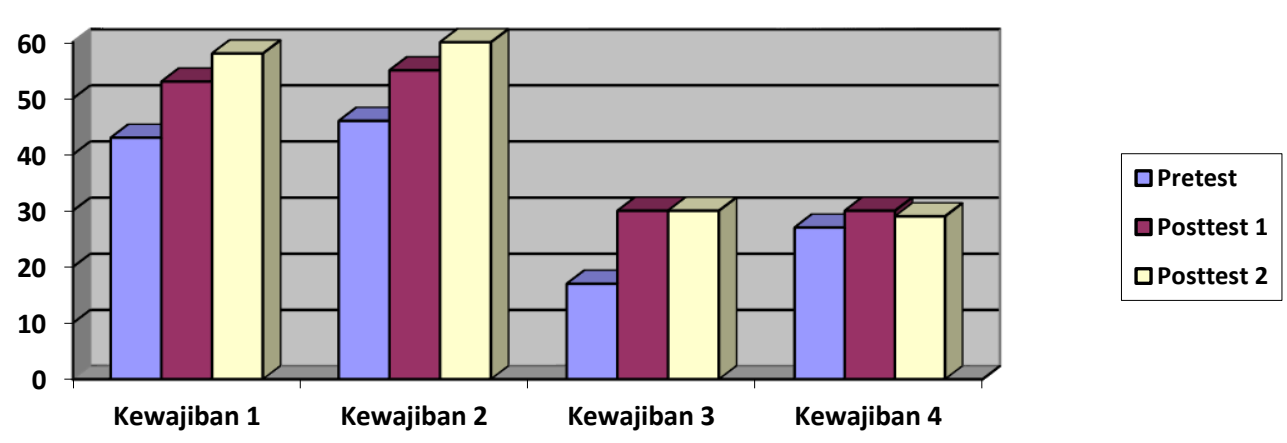

Gambar 3.

Hasil Pemahaman Anak Tentang Perilaku Respek Kepada Lingkungan

Dari gambar diagram di atas dapat dilihat adanya peningkatan skor pada semua indikator kewajiban utama manusia untuk respek kepada lingkungan. Indikator kewajiban untuk tidak melakukan sesuatu yang merugikan alam semesta memiliki enam item pertanyaan, dengan skor keseluruhan partisipan pada saat prates = 43 , pascates $1=53$, pascates $2=58$. Indikator kewajiban untuk tidak mencampuri memiliki enam item pertanyaan, dengan skor keseluruhan partisipan pada saat prates $=46$, pascates 1 $=55$, pascates $2=60$. Indikator kewajiban untuk kesetiaan kepada semacam "janji" terhadap binatang liar untuk tidak diperdaya, dijebak, dan dijerat memiliki tiga item pertanyaan dengan skor keseluruhan partisipan pada saat prates $=17$, pascates 1 $=30$, pascates $2=30$. Indikator kewajiban restitutif atau keadilan retributive memiliki tiga item pertanyaan dengan skor keseluruhan partisipan pada saat prates= 27 , pascates $1=30$, pascates $2=29$.

Dari hasil data yang diperoleh dapat diketahui adanya peningkatan skor pemahaman anak usia dini setelah mendapat intervensi melalui mendongeng yang diberikan guru dan yang dimoderatori keterampilan mendongeng. Setelah mendapatkan intervensi, hampir semua peserta mampu menjawab pertanyaan kuesioner tentang perilaku respek kepada lingkungan dengan lebih baik.

Analisis secara keseluruhan menunjukkan bahwa intervensi mendongeng efektif meningkatkan pemahaman anak usia dini tentang perilaku respek kepada lingkungan, yang dapat dilihat dengan adanya peningkatan pada skor rata-rata seluruh pendidik antara prates dan pascates. Efektivitas intervensi mendongeng masih menetap dua minggu setelah intervensi dilakukan.

\section{Pembahasan}

Dari hasil penelitian diketahui bahwa mendongeng cukup efektif untuk meningkatkan pemahaman anak usia 5-6 tahun tentang perilaku respek kepada lingkungan. Hal ini didukung beberapa faktor seperti isi dari cerita dongeng yang disampaikan dan ketrampilan mendongeng para pendidik anak usia dini. Dongeng dibuat sendiri oleh peneliti dengan menggunakan tokoh anak berusia 5-6 tahun 
dan tokoh-tokoh binatang yang merupakan satwa endemik Gunung Ciremai. Sebelum membuat dongeng, peneliti melakukan observasi terlebih dahulu tentang alam Gunung Ciremai, seperti apa saja flora dan faunanya yang ada di sana. Dipilih tiga satwa liar yang masih suka diburu, yaitu elang jawa, macan tutul, dan surili. Peneliti juga mencari tahu bagaimana ciri-ciri fisik mereka agar bisa dibedakan dengan famili mereka. Peneliti juga mencari tahu bagaimana karakteristik satwa, seperti suara dan kebiasaannya. Selain satwa peneliti juga mencari tahu jenis-jenis flora apa saja yang berada di Gunung Ciremai. Observasi ini dilakukan untuk melengkapi naskah dongeng dan pembuatan ilustrasi dongeng.

Ilustrasi dalam bentuk poster merupakan alat bantu para pendidik saat membacakan dongeng. Ilustrasi digunakan untuk memandu imajinasi anak, sehingga ilustrasi dibuat sebaik mungkin untuk menarik perhatian anak agar tetap fokus. Seperti yang dikatakan Shulevitz (1989, dalam Jalongo, 2004) bahwa gambar dapat menjelaskan dan melengkapi kata-kata dalam suatu cerita. Ilustrasi dan dongeng akan saling memperkuat isi cerita bahkan dapat melebihi makna yang tertulis di dalamnya (Temple, 1998, dalam Al- Somadi, 2012). Alur cerita pun dibuat sederhana, kewajiban utama manusia untuk respek kepada lingkungan pun dicontohkan oleh berbagai perilaku yang biasa ditemui dalam kehidupan sehari-hari, dan kehidupan masyarakat di kaki Gunung Ciremai pada khususnya. Kalimat dalam cerita, disusun dengan menggunakan bahasa yang sederhana dan lebih banyak berupa kalimat aktif.

Isi dari dongeng yang disampaikan bertema tentang respek kepada lingkungan, tema tersebut berdasarkan teori empat kewajiban manusia untuk respek kepada lingkungan (Taylor, dalam Keraf 2002). Empat kewajiban tersebut dijabarkan lagi dalam bentuk perilaku respek kepada lingkungan yang sering dilakukan anak usia 5-6 tahun di sekolah dan dikaitkan dengan lingkungan tempat tinggal mereka yang berada di kaki Gunung Ciremai. Ada empat dongeng, yang tiap-tiap ceritanya mengandung salah satu kewajiban utama manusia untuk dapat respek kepada lingkungan. Isi cerita dongeng dikemas sedemikian rupa untuk membuat anak berimajinasi dan tersentuh hatinya, sehingga bisa menimbulkan keinginan untuk respek kepada lingkungan. Selain itu pengetahuan lain yang didapatkan anak, begitu juga pendidik, dari dongeng ini adalah mereka menjadi tahu bahwa Gunung Ciremai yang berada di lingkungan tempat tinggal mereka memiliki hewan-hewan endemik yang terancam punah dan flora endemik yang harus dijaga kelestariannya.

Dari hasil analisis kebutuhan para pendidik, dapat diketahui bahwa mereka jarang menggunakan metode mendongeng, mereka lebih sering membacakan cerita kepada anak dari sebuah buku. Dari hasil analisis tersebut pun diketahui karena para pendidik tidak memiliki kemampuan mendongeng maka mereka pun memiliki motivasi untuk belajar mendongeng. Oleh karena itu, sebelum memberikan intervensi, pendidik anak usia dini diberikan pelatihan mendongeng terlebih dahulu. Mereka diberikan beragam materi seperti pengetahuan tentang respek kepada lingkungan, manfaat mendongeng, aspekaspek mendongeng, jenis-jenis dongeng, dan hal-hal yang harus diperhatikan ketika mendongeng.

Para pendidik belum sepenuhnya mengetahui kewajiban-kewajiban apa saja yang harus dilakukan manusia sebagai pelaku moral untuk bisa respek kepada alam. Para pendidik hanya mengetahui secara umum bagaimana cara menjaga lingkungan seperti tidak melakukan sesuatu yang merugikan alam dan isinya, seperti membuang sampah pada tempatnya. 
Sebelum para pendidik diberikan materi tentang mendongeng, mereka diberikan materi terlebih dahulu tentang respek kepada lingkungan, karena pendidik akan menjadi panutan bagi siswa dengan menjadi seseorang yang menunjukkan tingkat respek yang tinggi baik di kelas maupun di luar kelas (Lickona, 1992), sehingga pendidik pun harus mengetahui dan memahami apa itu respek kepada lingkungan dan apa saja kewajiban utama manusia untuk dapat respek kepada lingkungan.

Setelah diberikan pengetahuan tentang respek mereka pun diberikan materi tentang mendongeng. Sebelum mengikuti pelatihan, para pendidik masih menganggap bahwa mendongeng itu sekedar membacakan cerita dari sebuah buku tanpa perlu menggunakan teknik-teknik tertentu. Oleh karena itu dalam pelatihan mendongeng, para pendidik diberikan materi tentang dongeng secara umum seperti manfaat, aspek-aspek mendongeng, tipe-tipe mendongeng untuk meningkatkan moral anak, jenis-jenis dongeng, teknikteknik mendongeng, dan hal-hal yang harus diperhatikan ketika mendongeng. Dalam pelatihan ini para pendidik juga diberikan praktik mendongeng. Hampir seluruh pendidik mendongeng dengan cara yang sama, duduk di atas sebuah kursi sambil memegang buku dongeng. Ketika membacakan dongeng, para pendidik hanya membaca seperti sedang membacakan cerita dari sebuah buku dan tidak melakukan interaksi dengan audiens. Setelah mendapatkan pengarahan dari fasilitator, para pendidik pun mulai menggunakan teknik-teknik mendongeng dan mulai memperhatikan hal-hal yang harus diperhatikan ketika mendongeng seperti ekspresi wajah, intonasi, gerak tubuh, kontak mata, pemilihan kata, teknik mendongeng, rileks dan percaya diri.

Pelatihan ini dilakukan sebagai prasyarat bagi para pendidik yang akan melakukan intervensi, karena metode mendongeng berguna bagi para pendidik untuk mengajarkan karakter baik jika metode dipersiapkan dengan baik. Pelatihan diberikan para pendongeng profesional yang berasal dari komunitas dongeng Bengkimut, sebuah komunitas mendongeng dari Kota Bandung. Pemateri dipilih atas dasar pertimbangan masalah bahasa daerah, karena penelitian di daerah pelosok yang masih kental dengan budaya Sunda, maka dipilihlah pemateri yang mampu berbahasa Sunda. Ketika pelatihan berlangsung, pendidik bisa leluasa bertanya tentang halhal yang tidak mereka pahami tentang mendongeng. Para pendidik pun diberikan evaluasi sehingga para pendidik mengetahui kelebihan dan kekurangan mereka, agar mereka bisa mempersiapkan diri mereka dengan baik sebelum memberikan intervensi.

Pada pelatihan mendongeng ini, pendidik memperoleh pengalaman konkret dari mendongeng. Mereka pun merefleksikan dan mengamati pengalaman mendongeng yang mereka peroleh dan memberikan penilaian terhadap cara mendongeng mereka masing-masing. Di akhir pelatihan, para pendidik mengambil kesimpulan dari pengalaman pelatihan mendongeng yang mereka terima. Untuk lebih efektif, para pendidik pun menguji pengetahuan dan keterampilan mendongeng yang mereka punya kepada para anak didiknya dengan melakukan intervensi mendongeng.

Tidak semua pendidik memberikan intervensi, hanya pendidik yang memiliki skor tertinggi pada saat pelatihan mendongeng, baik untuk skor pengetahuan maupun skor ketrampilan. Saat pelatihan, ketiga pendidik yang memperoleh skor tertinggi ini terlihat aktif dan memiliki motivasi yang cukup tinggi untuk belajar mendongeng jika dibandingkan dengan ketiga pendidik lainnya. Ketika praktik mendongeng, mereka pun melakukannya dengan maksimal dan percaya diri, selalu 
melakukan kontak mata dan menyesuaikan penyampaian cerita secara spesifik, sehingga lebih terhubung dan personal dengan para pendengarnya. Mereka pun mampu mengatasi kendala teknis, seperti anak yang kehilangan konsentrasinya ketika sedang mendengarkan dongeng, dengan cara kreatif.

Satu pendidik memegang satu kelas yang berisi kurang lebih 10 anak. Pada penelitian yang dilakukan Keup dan Mulote (2014), pembacaan cerita efektif dilakukan pada kelompok kecil (6-10 anak). Mereka memberikan intervensi mendongeng yang dimoderatori ketrampilan mendongeng kepada anak usia dini untuk meningkatkan pemahaman anak tentang respek kepada lingkungan.

Pada awalnya anak masih asing dengan istilah respek kepada lingkungan. Akan tetapi setelah dibacakan dongeng, anak menjadi tahu tentang istilah respek kepada lingkungan. Mereka memang belum bisa menjelaskan arti respek kepada lingkungan, tapi mereka sudah paham dan mengetahui apa saja perilaku yang mencerminkan sikap respek kepada lingkungan. Untuk membiasakan anak dengan kalimat respek kepada lingkungan, ketika membacakan dongeng, pendongeng selalu menyebutkan kalimat tersebut ketika akan memulai mendongeng dan ketika refleksi setelah mendongeng. Pendongeng juga mengulang kembali kalimat respek kepada lingkungan dan perilaku-perilaku respek kepada lingkungan dari dongeng yang sudah dibacakan, sebelum memulai membacakan dongeng kembali. Dari cerita dongeng yang disampaikan pendongeng, mereka menjadi paham untuk membuang sampah di tempat sampah, menjaga lingkungan, tidak menyakiti binatang, tidak menjerat dan berburu hewan-hewan langka, merawat tanaman, serta bertanggung jawab jika ada perbuatan yang merugikan dan merusak lingkungan.
Dari hasil penelitian yang dilakukan terhadap 31 anak didapatkan peningkatan nilai rata-rata antara skor prates dengan nilai rata-rata pascates 1 pemahaman anak tentang respek kepada lingkungan, setelah diberikan intervensi mendongeng oleh para pendidik yang sebelumnya diberikan ketrampilan mendongeng. Semakin trampil pendidik mendongeng, semakin besar nilai rata-rata pemahaman anak. Hasil uji statistik menunjukkan perbedaan nilai rata-rata yang signifikan antara prates_dan pascates 1 . Peningkatan menandakan bahwa mendongeng cukup efektif meningkatkan pemahaman anak usia 5-6 tahun tentang respek kepada lingkungan.

Dari penelitian ini juga diketahui pendidik lebih trampil mendongeng dengan bantuan ilustrasi tanpa teks. Mereka mampu berimprovisasi dan mengembangkan jalan cerita sesuai degan kemampuan dan gaya bercerita masing-masing serta berinteraksi dengan para audiens. Beda halnya ketika mereka bercerita dengan menggunakan buku dongeng, mereka tidak bebas bergerak, lebih sering melihat ke buku dari pada melakukan kontak mata dengan anak. Keluwesan mendongeng membuat para pendidik bisa mendongeng kurang dari 20 menit, hal ini menjadi penting karena rentang perhatian anak yang pendek tidak selalu membuat anak untuk tetap fokus dan antusias dibacakan dongeng. Setiap pendidik mampu membacakan dongeng kurang lebih 15 menit, termasuk dengan refleksi dongeng. Hauser-Lindstrom dan Steinfelt (1998) menyatakan bahwa rentang perhatian anak usia 6-8 tahun kurang lebih 20 menit dan anak usia 5-6 tahun kurang dari 20 menit. Hal ini terbukti, ketka sudah lebih dari 10 menit banyak anak yang sudah mulai tidak fokus mendengarkan dongeng.

Dalam rangka menguatkan nilainilai respek kepada lingkungan, anak yang sudah dibacakan dongeng membuat surat perjanjian yang dibubuhi nama. Surat perjanjian ini akan dipegang pendidiknya 
masing-masing yang bisa digunakan sebagai pengingat mereka ketika melakukan hal yang tidak respek kepada lingkungan. Selain itu anak diberikan bibit kangkung yang harus mereka rawat dan jaga untuk mengembangkan pemahaman perilaku respek yang mereka punya menjadi sebuah tanggungjawab. Mereka harus merawat tanaman tersebut hingga bisa dipanen. Pendidik akan mengobservasi apakah anak tetap melakukan perilaku respek kepada lingkungan dengan menepati janji untuk tidak membuang sampah sembarangan, tidak menyakiti binatang, tidak mengurung binatang, dan merawat tanaman milik mereka sendiri. Hal tersebut akan membantu anak belajar dan diberikan kesempatan untuk melihat, merasakan dan melakukan perilaku respek kepada lingkungan Hal ini sesuai dengan apa yang dikatakan Borba (2001) bahwa suatu cara untuk membantu anak dalam memahami respek kepada lingkungan adalah dengan memberikan contoh dan memberikan pengalaman kepada anak. Kedua hal ini juga bermanfaat agar pemahaman respek kepada lingkungan anak yang diterima setelah mendapatkan intervensi mendongeng bisa tetap bertahan hingga dilakukan pascates 2 . Dari hasil pengamatan yang dilakukan pendidik, dapat diketahui bahwa anak tetap konsisten untuk berperilaku respek kepada lingkungan. Jika ada salah satu anak yang buang sampah sembarangan, merusak tanaman, atau menyakiti binatang, anak yang lain akan mengingatkan untuk tidak melakukan hal tersebut. Jika peringatan dari anak tidak dihiraukan, maka pendidik yang akan langsung mengingatkan anak tersebut. Anak-anak juga terlihat konsisten dan antusias untuk merawat tanaman masingmasing, para pendidik membuat daftar untuk setiap anak apakah mereka merawat tanaman mereka setiap hari atau tidak. Pengamatan ini dilakukan selama dua minggu setelah pascates 1 dilakukan, sehingga ketika diberikan pascates 2 , anak mampu menjawab pertanyaan dengan baik. Sebagian besar anak skornya tetap dan meningkat dari pascates 1 . Hanya sebagian kecil anak yang skornya menurun dari hasil pascates 1 .

Ketika memberikan prates dan pascates kepada anak, hindari menggunakan pertanyaan yang membuat anak harus menjawab dengan kalimat panjang. Hal ini dikarenakan saat usia dini anak masih belum bisa berbicara dengan kalimat panjang. Ketika anak ditanya tentang dongeng apa yang diberikan kepada mereka, mereka tidak bisa menjawab. Akan tetapi, apabila pertanyaan yang diberikan membutuhkan jawaban pendek, anak bisa dengan mudah menjawabnya. Anak tidak bisa menjawab secara konkret sebuah pertanyaan yang abstrak seperti "Kamu tahu apa itu respek kepada lingkungan?" Mereka akan menjawab dengan contoh perilaku yang mereka tahu dan dengarkan dari dongeng yang dibacakan kepada mereka.

Penelitian ini juga memiliki beberapa faktor keterbatasan seperti pembuatan ilustrasi dongeng membutuhkan waktu yang cukup lama. Untuk mendapatkan hasil yang maksimal satu dongeng membutuhkan waktu satu bulan pengerjaan. Oleh karena keterbatasan waktu, maka peneliti pun menggunakan tiga ilustrator yang berbeda, padahal dongeng yang disusun peneliti adalah dongeng berseri yang mana tokoh yang berada di dalam dongeng sama. Hal tersebut menyebabkan ilustrasi yang dihasilkan memiliki gaya dan wajah yang berbeda, walaupun memiliki tokoh yang sama. Saat pembuatan ilustrasi pun tidak terlalu berjalan mulus, karena konsep yang diberikan seringkali berbeda saat dituangkan dalam bentuk ilustrasi, sehingga sering dilakukan revisi.

Pada saat melakukan intervensi, para pendidik menggunakan ilustrasi berupa poster sebagai alat bantu. Satu dongeng kurang lebih menggunakan 12 
poster, sehingga pendidik sedikit kesulitan mengatur poster-poster tersebut ketika sedang mendongeng karena ukuran poster yang besar dan cukup berat.

Jumlah ko-fasilitator pada saat pelatihan terterbatas, sehingga fasilitator harus memegang peran ganda sebagai dokumentasi dan teknisi. Karena penelitian dilakukan di kaki gunung, fasilitator pun mengalami kendala teknis terkait alat bantu pelatihan.

Penelitian ini dilakukan di sekolah oleh pendidik anak usia dini yang hanya bisa ditemui anak pada saat di sekolah. Sehingga pemahaman perilaku respek kepada lingkungan yang diberikan kepada anak, belum tentu bisa dilakukan di rumah mengingat orang dewasa yang berada di rumah belum tentu memahami perilaku respek kepada lingkungan. Perlu dilakukan kerjasama antara pendidik dan orangtua agar perilaku respek kepada lingkungan bisa dilakukan terus menerus hingga menetap menjadi sebuah karakter demi mengurangi krisis lingkungan hidup yang sedang terjadi saat ini.

\section{Simpulan dan Saran}

\section{Simpulan}

Berdasarkan hasil pengolahan data penelitian, terdapat perbedaan yang signifikan dari nilai rata-rata antara prates dan pascates pengukuran pemaham respek anak kepada lingkungan. Sehingga dapat disimpulkan mendongeng cukup efektif untuk meningkatkan pemahaman anak usia 5-6 tahun tentang perilaku respek kepada lingkungan.

\section{Saran}

Berdasarkan kesimpulan dan diskusi dari hasil penelitian dapat dirangkum beberapa saran untuk meningkatkan pengetahuan dan ketrampilan mendongeng para pendidik serta meningkatkan pemahaman anak usia 5-6 tahun melalui mendongeng, yaitu:

1. Penelitian ini memiliki rangkaian yang cukup panjang, sehingga persiapkan estimasi waktu agar penelitian bisa dilakukan dengan maksimal.

2. Saat melakukan prates dan pascates kepada anak dilakukan di ruang yang berbeda, dan usahakan bertatap muka dengan anak. Jangan disatukan dalam satu ruangan untuk mencegah hilangnya konsentrasi dan fokus anak.

3. Pembuatan ilustrasi dongeng harus kontekstual. Misal warna rambut orang Indonesia tidak ada yang berwarna pirang.

4. Jangan memberikan konsep mentah berupa naskah kepada ilustrator, karena sangat besar kemungkinan ilustrasi yang kita bayangkan sesuai dengan bayangan ilustrator. Sebelum pembuatan, ilustrasi sebaiknya didiskusikan terlebih dahulu dengan pembuatan sketsa agar menyamakan imajinasi. Usahakan ketika membuat dongeng berseri, ilustrasi dongeng yang satu dengan dongeng yang lainnya sama. Hal ini berfungsi untuk memudahkan pendongeng dan audiens mengenal tokoh dongeng. Jangan terlalu banyak menyertakan tokoh dongeng.

5. Saat pelaksanaan intervensi mendongeng, pastikan satu pendongeng, satu kelas, memiliki satu observer.

6. Persiapkan ko-fasilitator lebih dari yang dibutuhkan untuk mengantisipasi kendala teknis dan nonteknis saat melakukan penelitian.

7. Diperlukan penelitian lanjutan agar pembelajaran perilaku untuk respek kepada lingkungan juga bisa dilakukan di lingkungan rumah bersama orang tua. 


\section{Daftar Pustaka}

Al-Somadi, M. F. (2012). The effect of a storybased programme on developing moral values at the kindergarten stage. Interdisciplinary Journal of Contemporary Research in Business, 4(7), 534-559.

Ärlemalm-Hagsér, E. (2013). Respect for nature - A prescription for developing environmental awareness in preschool. CEPS Journal : Center for Educational Policy Studies Journal, 3(1), 25-44. Retrieved from https://search.proquest.com/docvie $\mathrm{w} / 1346762436$ ? accountid $=17242$

Bae, N. Y. (2014). The development of children's respect and relations to prosocial behaviour (Order No. 1603871). Available from ProQuest Dissertations \& Theses Global.(1736050083). Retrieved from https://search.proquest.com/docvie $\mathrm{w} / 1736050083$ ?accountid=17242.

Borba, M. (2001).Building moral intelligence. The seven essensial virtues that kids to do the right thing. San Fransisco. CA:A Willey Imprint.

Bream, Terry. (2011). The Power of Storytelling. Januari 2017. http://www.docstoc.com/docs/9817 1934/The-Power-of-StorytellingTerry-Bream-elling-stories-is.

Ceepo, (2013).Gunung Ciremai Jadi Ajang Perburuan Liar. April 2016. http://www.jurnalcirebon.com/gunu ng-ciremai-jadi-ajang-perburuanliar.html .

Eder, D., \& Holyan.(2010). Life Lessons through Storytelling. Children's Exploration of Ethics. Bloomington: Indiana University Press.
Djauhari, Djamila. (2012). Program Pelatihan Mendongeng Untuk Meningkatkan Kemampuan dan Frekuensi Ibu Mendongeng Dalam Usaha Mengurangi Masalah Perilaku Anak Usia 4-6 Tahun Pada PAUD AlQoshosh.Thesis. Fakultas Psikologi Universitas Indonesia: Depok.

Fauzi, A. Ikka Kartika (2011). Mengelola Pelatihan Parsitipatif. Alfabeta: Bandung.

Febiana. (2007). Pengalaman dan pemahaman dongeng pada siswa kelas IV SD dari golongan Sosial-Ekonomi Berbeda. Skripsi. Fakultas Psikologi Universitas Indonesia: Depok.

Fraenkel, R. J., Wallen, E. N., \& Hyun, H. H. (2012).How to design and evaluate research in education, New York: Mc Graw Hill.

Gardner, G. T., \&Stern, P. C. (1996). Environmental Problems and Human Behavior.Boston, MA Allyn \& Bacon.

Hauser-Lindstrom, \& Steinfelt.(1998). Ages and Stages: 4 to 8 year olds. Cooperative Extension, College of agriculture \& Life Science.The University of Arizona. http://ag.arizona.edu/pubs/family/a z1036.html.

Henniger, L. M., (2009).Teaching Young Children, Ohio: Pearson.

Jalongo, M. R. (2004). Young children and picture book (2nded). Washington DC: NAEYC. 
Kahriman-Ozturk, D., Olgan, R., \& Tuncer, G. (2012). A Qualitative Study on Turkish Preschool Children's Environmental Attitudes Though Ecocentrism and Anthropocentrism.International Journal of Science Education, 34(4), 629-650.

Keraf, S. (2002).Etika Lingkungan. Jakarta: Penerbit Buku Kompas.

Keup, J., \& Mulote, R. (2014).Supporting moral development in early childhood through storybooks. Helsinki Metropolia University of Applied Sciences.

Knowles, S. Malcolm (1998). The Adult Learner ( $5^{\text {the }}$ ). Gulf: Houston

Kurniawan, Heru. (2013). Keajaiban mendongeng. Jakarta: PT. Buana Ilmu Populer.

Kusmiadi, Ade. (2008). Strategi Pembelajaran PAUD Melalui Metode Dongeng Bagi PendidikPAUD. Jurnal Ilmiah VIVI PTK-PNF-Vol.3,No.2-2008, 198-203. 7 September 2016. http://isjd.pdii.lipi.go.id/admin/iurna 1/3208198203.pdf

Laird, Dugan (2003).Approaches to training and development. $3^{\text {rd }}$ edition. USA: Perseus Publishing.

Lane, H. B., \& Wright, L.W. (2007). Maximizing the effectiveness of reading aloud. The Reading Teacher, 60(7), 668-675. doi:10.1598/RT.60.7.7

Lickona T. (1991). Educating for character. How our school can teach respect and responsibility. New York: Bantam Books.Mathis \& Jackson (2005).Human Resources Management Essential Perspectives ( ${ }^{r d e d}$.). Thompson South Western: Canada.

Munandar.(2001). Psikologi industri dan organisasi.Jakarta: UI Press.
Mus, (2014).Pemburu Burung Berkeliaran di Ciremai. April 2016. http://www.radarcirebon.com/pemb uru-burung-berkeliaran-diciremai.html .

Musfiroh, T. (2008).Memilih, menyusun, dan menyajikan cerita untuk anak usia Dini.Yogyakarta: Tiara Wacana.

Noviantoro, Djatmiko. (2009). Analisis Pengaruh Pelatihan dan Pengembangan Serta Kompensasi Terhadap Kinerja Pegawai Pada PT. Perusahaan Perkebunan Lonson Sumatera Indonesia Tbk Medan. Thesis: Sekolah Pascasarjana Universitas Sumatera Utara Medan.27 Desember 2017.

http://library.usu.ac.id/download/fk m/fkm-rozaini.pdf.

Olson, J. K. \& Iwasiw, C. L. (1987). Effects of a Training Model on Active Listening Skills of Post-RN Students.The Journal of Nursing Education.Diunduh dari http://www.ncbi.nlm.nih.gov/pubme d/3035116.

Papalia.,\& Marorell. (2014). Experience human development (13thed). New York: McGraw - Hill Education.

Rahasya, M. Keisha. (2017). Teaching good character in a narrative text through storytelling. Journal of English and Education, [S.l.], v. 5, n. 2, p. 145-153, feb. 2018. Available at: $<$ http://ejournal.upi.edu/index.php/L -E/article/view/9944/6337>.

Santrock, J.W. (2007). Perkembangan anak, Jakarta: Penerbit Erlangga.

Serrat, Oliver. (2008). Storytelling.19 Januari 2018.

http://digitalcommons.ilr.cornell.edu Lcgi/viewcontent.cgi

Silberman, Mel. (2006). Active learning a handbook of techniques designs case examples and tips. Pfeiffer: USA. 
Speaker, McGrath Kathryne. (2000). The art of storytelling : a collegiate connection to professional development schools. Education; Fall 2000: 121, 1; ProQuest Research Library

Thompson, K. L., \& Gullone, E. (2003). Promotion of emphaty and prosocial behavior in children through humane education. Article in Australian Psychologist.Doi: 10.1080/00050060310001707187. http://www.researchgate.net/publica $\underline{\text { tion/228690635 }}$
Thompson, M. (2011).Developing moral values in children: observations from a preschool. Iife Psychologia, 19(2), 394411. Retrieved from https://search.proquest.com/docvie $\underline{w} / 893188870$ ?accountid $=17242$

What Works Clearing House. (2007). Dialogic reading. Early childhood education. Institute of Education Sciences.

Whitehurst, G. (2009). An effective way to read to pre-schoolers. Retrieved from: www.readingrockets.org/article/dial og-reading-effective-way-readpreschoolers 